TaT - Texts around Theater - TaT

\title{
To the Theatre!
}

\section{Lili Grün}

The rubric Texts around Theatre features historical and contemporary crosscultural and culture-specific perspectives on theatre - unexpectedly funky, unusually enthralling, disturbingly fascinating.

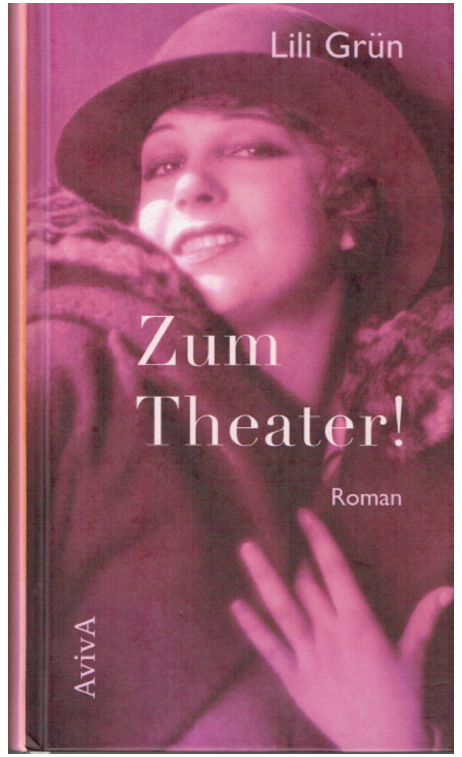

Figure 1: //www.aviva-verlag.de/autor-innen-co/lili-gr\%C3\%BCn/

Young Loni Holl, the protagonist in Lili Grün's autobiographical novel, desires to become an actress. Only the theatre gives Loni the feeling of escape from her boring day to day life. She pursues her goal with determination, and a theatre engagement in the province seems to be the long-awaited chance for her debut. She straddles rehearsals, performances and private life; learning her lines, paying her rent, and allaying her hunger. The following excerpt from Grün's novel , first published in 1935, traces Loni's first steps on the stage that means the world to her.

Apart from Zum Theater, Lili Grün also wrote the cabaret novel Herz über Bord (now in a new edition as Alles ist Jazz) in 1993. Mädchenhimmel, a collection of poems and stories was first published in 2014. Her novel Junge Bürokraft übernimmt auch andere Arbeit ..., first published 1936/37 in the newspaper "Der Wiener Tag", was issued in book format in 2016 (all edited by Anke Heimberg). As a Jewish author, Lili Grün was not allowed to publish after 1938. In 1942, she was murdered at the concentration camp Maly Trostinec in Belarus. 
The tension rises. Soon, the performance will begin, and Kurt Brambach, who is doing the introduction, will say a few charming words about Loni and then send her onto the stage without mercy... Loni thinks: I would like to get sick and go home and I know it will be terrible, I will get stuck, they will laugh at me.

"Hi my dears, hi you all!"

That, of course, is Hartenstein. In a black velvet suit. Why ever would she wear skirts this short? Her legs aren't exactly beautiful. Now she has recognized Ms Sonja Müller and greets her exuberantly. Brambach is wearing a tux and small, blond Fred Markus has a monocle today, for the first time.

"Who is missing?" asks Brambach severely.

Missing: Mr Gottlieb Stangl, who will sing lieder and accompany himself on the lute, and Miss Betty Bierbach, who has studied dance in Vienna for two years and will interpret "local music" in a wholly new and individual way. Both are participating as a favor. They will not have to worry about a lack of applause.

Hartenstein has sat down next to Sonja Müller and is talking with animation, gesturing a lot. Sonja Müller is nodding at everything she hears and says yes or no from time to time.

Kurt Brambach calls them. "Ladies and gentlemen, this will be quite a disaster. I have prepared no introduction at all." He inserts his monocle and chuckles.

Standing in a corner in a dispirited way, small Markus is soundlessly moving his lips. He is memorizing text.

Betty Bierbach and Mr Gottlieb Stangl have arrived. Behind them Mrs Wind appears. She wrings her hands: "My dearest Mr Braunbach... everyone is here. I'm afraid we need to begin."

"You're afraid, madam ... I'm afraid. But no, don't be afraid, folks - chin up, and break a leg."

He hurries out. The performance is set to begin. Mrs Wind rushes out behind him in a rustle of taffeta: "Mr Brambach, another thing." The others remain behind in silence. Eva Hartenstein clears her throat. They are listening intently to the sounds from the auditorium next door. A bell rings, and rings again. "Quiet!" somebody calls, and someone else: "Excuse me - waiter!"

Applause. Kurt Brambach has stepped onto the stage. They can hear what he is saying. Loni has had it memorized for a long time, how he will wittily explain that none of his colleagues wants to be first on the program. For this reason, he says, he has cancelled the first spot altogether, and second on the program is Kurt Brambach with his magic tricks...

"Here, look, ladies and gentlemen ... both my palms are empty ..."

Loni sighs. The endless agony of these minutes is a thousand times worse than any stage fright she has experienced so far. Betty Bierbach has returned from an improvised changing room, she is wearing a pink tunic which hangs shapelessly from her thin, small body. She stands in a corner, her face serious 
and unmoving, and rehearses dance moves. Gottlieb Stangl is picking out notes on his lute. Loni is feeling deathly sick. She takes in Kurt Brambach's return through a haze of racing heartbeats and stomach pains. Betty Bierbach in her pink tunic, with naked legs, goes out to dance. The audience applauds. Betty Bierbach returns beaming, her face glows. The audience is still applauding. Lightfooted, she flits back into the auditorium to bow again. She finally tumbles into the room, breathless and hot, with flowers in her hands.

"Now I'll get changed and then I'll watch you all", she promises benevolently, before she leaves for the changing room.

Gottlieb Stangl sings the song of Hans and Liese.

"Get ready", Kurt Brambach whispers to Loni.

Loni looks beseechingly at him. Couldn't she quickly fall deathly ill, she wonders. But she knows herself that she couldn't.

Kurt Brambach interrupts the interminable applause after Gottlieb Stangl's performance and announces "our dear little Loni Holl" among the receding noise of clinking glasses and clattering plates. The pianist takes a sip of his beer and plays a fanfare for Loni. Kurt Brambach kisses Loni's hand and leads her to the stage. Without a partner, without props or scenery, alone and forlorn, left to face a harsh and merciless fate, she remains there. A miracle: she is talking, moving, laughing. She plays her poetry all by herself. She recognizes Mr Mahlmann the pharmacist, and Dr Liebig, and Mr Neruda, the grocer from St. James' Lane. In the first row is Mrs Angelika Wind, she is smiling continually with her pinkish-white face. Her eyes are half shut, her head sinks slowly onto her chest, her left shoe stands all by itself under the table.

Cheerful, laughing applause begins. Mrs Angelika Wind wakes up, she claps briskly.

Loni returns to the stage and bows. She takes another bow and realizes: I will have to give an encore.

The restlessly humming, laughing, clapping crowd slowly quiets, a father calls, whispers his kids to order. The waiter brings cake. Now it has become quiet ... Loni begins to speak once more.

In: Lili Grün (2001): Zum Theater! Novel. Edited with an Afterword by Anke Heimberg, Berlin, AvivA Verlag, 151-155.

Translated by Silja Weber. 